\title{
Urban planning development by ensuring the competitiveness of construction enterprises
}

\author{
Olena Uhodnikova \\ Department of Tourism and Hospitality \\ Business \\ O.M. Beketov National University of \\ Urban Economy in Kharkiv \\ Kharkiv, Ukraine \\ ORCID 0000-0003-2218-0041
}

\author{
Kostiantyn Viatkin \\ Department of Urban Construction \\ O.M. Beketov National University of \\ Urban Economy in Kharkiv \\ Kharkiv, Ukraine \\ ORCID 0000-0002-2394-3779
}

Ruslan Sheludko

Department of marketing,

entrepreneurship and production

$$
\text { organization }
$$

Kharkiv National Agrarian University

Named After V.V. Dokuchaiev

Kharkiv, Ukraine

ORCID 0000-0001-5287-2773

\author{
Sergiy Kobzan \\ Department Land administration and \\ geoinformation systems \\ O.M. Beketov National University of \\ Urban Economy in Kharkiv \\ Kharkiv, Ukraine \\ ORCID 0000-0002-5257-8117
}

\begin{abstract}
This article is devoted to the topical issue of finding effective models of urban development support. Increasing the information component, automating management processes and involving the local population in solving the problem of urban and territorial development were considered the priorities of the urban planning system. One of the key functions of the urban planning system is to ensure the development of infrastructure, comfortable and safe living, transport accessibility and quality provision of housing and utility services. Increasing the efficiency of these processes can be ensured by the interaction of two systems: urban and construction on the way to ensuring socio-economic development. Analysis of the specificity of the construction industry showed that it is advisable to consider separately the specificity of construction processes, and separately the specificity of the construction product, as these specific factors affect the formation of competitiveness of the construction industry. The factors analyzed for construction factors competitiveness were grouped into the following blocks: regulatory, technical, economic, social, political, relations with local authorities, some of which were separated on the basis of internal or external relation to the construction enterprise. Further analysis allowed to identify the key elements of competitiveness for each functional unit and analyzed their potential impact on the competitiveness of the construction enterprise. The analysis of the interconnections of the blocks of construction enterprises competitiveness with the urban planning system made it possible to determine their impact on the socio-economic development of cities and territories. On the basis of the conducted analysis, recommendations on ways of model formation of urban planning systems development were developed in order to increase the competitiveness of the construction sector. Analyzing the interdependence of urban planning decisions and its impact on the competitiveness of construction enterprises, as well as analyzing feedback, the article applied methods of the simulation modeling.
\end{abstract}

Keywords-innovative models of urban planning system development, urban planning system, construction enterprises, competitiveness, socio-economic development.

\section{INTRODUCTION}

In the conditions of reforming the system of public administration, administrative-territorial structure and implementation of innovative approaches to decentralization processes to ensure socio-economic development, processes of "smart" management of cities and territories become especially relevant. The development of the information oriented society and the increasing demands for quality services to the population are challenging scientists to find innovative models of urban and territorial development. Given the need for infrastructure modernization, reconstruction and upgrading, finding ways to more effective realization the socio-economic potential of cities and territories, construction is an important element of the urban planning system. The field of construction is developing practically without regional competition. Powerful construction companies that have covered most of the construction market in individual regions do not have the motivation to increase their own competitiveness, because in the context of the distribution of economic impact on the construction market, construction enterprises do not have the task of expanding markets to other regions or entering European markets. Therefore, the lack of preconditions for ensuring the competitiveness of construction enterprises is a negative factor in providing the population of cities and territories with quality, reliable and economically justified construction products, which significantly impedes the processes of urban development and the entry of domestic enterprises into European markets.

\section{ANALYSIS OF RECENT RESEARCH AND PUBLICATIONS}

The issues of competitiveness analysis of construction enterprises are devoted to the work of many domestic and foreign scientists, which is determined by the relevance of this topic to ensure economic development. In particular, the competitiveness of construction enterprises was considered 
in the works of Dykan V.L., [1], Shcherbinina S. A., Kryvoruchenko A. V., Kiselyova I. R. [2], Pastukhova T.Yu.,[3] Rossikhina O.Ye. [4], Smachylo V.V., GolovkoMarchenko I.S. [5] and others.

\section{HIGHLIGHTING A PREVIOUSLY UNRESOLVED PART OF THE OVERALL PROBLEM}

Despite the great interest of the scientific community in the issues of ensuring the construction competitiveness, however, the relationship between the processes of development of urban systems and the transformation of the competitiveness factors of construction enterprises to ensure the socio-economic development of cities and territories has not been sufficiently studied.

\section{PURPOSE AND OBJECTIVES OF THE STUDY}

The purpose of the study is to find effective mechanisms for ensuring the competitiveness of construction enterprises for the formation of modern models of urban development systems that are comfortable for the life of the population, taking into account the strategic directions of socioeconomic development.

To achieve this goal, the following tasks were outlined:

- to identify the main aspects of innovative urban and territorial development;

- to analyze the specifics and to structure the competitiveness of the construction sector;

- to analyze the interdependencies between urban and territorial development and ensure the competitiveness of construction enterprises;

- to suggest ways to increase the competitiveness of construction enterprises to ensure the effective urban and territorial development.

\section{STATEMENT OF THE BASIC MATERIAL}

The modern information society defines the priorities for the development of cities and territories, among which are:

- accessibility of the population to meeting social needs and provision of administrative services,

- automation of systems for managing socio-economic development of cities and territories,

- informatization of processes of life support of cities and territories, automation of processes of monitoring and control of socio-economic development,

- involvement of local population in solving problems of urban and territorial development;

- ensuring the development of infrastructure, comfortable and safe accommodation, transport accessibility and quality provision of housing and communal services;

- transparency and efficiency in managing urban and territorial development processes.

According to the current legislation there is the notion of urban planning or urban planning activities, which is characterized as: "purposeful activity of state bodies, local self-government bodies, enterprises, institutions, organizations, citizens, associations of citizens in creating and maintaining a complete living environment, which includes urban and territorial development forecasting, planning, construction and other use of territories, design, construction of urban development objects, construction of other objects, reconstructions structure of historical settlements while preserving the traditional nature of the environment, restoration and rehabilitation of cultural heritage sites, creation of engineering and transport infrastructure" [6] .

The modern paradigm of urban and territorial development should be based on the provisions of the concept of sustainable development, which defines the harmonious interaction of three aspects of social life: economic, social and environmental. The effectiveness of territorial development is determined by the implementation of processes for providing "reasonable" mechanisms of life support. An important factor is the transparency, information and automation of service delivery.

The transition from postindustrial to information society, causes change of the vector of providing strategic development processes. Now it is not enough to just offer the population a service of the right quality level. In the context of the information oriented society, much attention in the system of urban development management should be given to information and communication systems, including the establishment of processes for the construction of new real estate and infrastructure, reconstruction and modernization of existing facilities. In the context of the formation of new approaches to the strategic development of socio-economic systems, it is advisable to pay attention to the transformation of factors of ensuring the competitiveness of certain sectors of the economy.

While forming competitiveness as a systemic economic category, it is advisable to pay particular attention to industry specificity, because it is this specificity that will determine the set of factors of influence and conditions of their interaction to ensure the competitive advantages of an enterprise of a particular industry. In particular, V.V. Smachylo and I.S. GolovkoMarchenko proposed to define the specific characteristics of the construction industry in two aspects: in terms of the specificity of finished construction products, and taking into account the specific characteristics of the construction process itself [5].

Among the special characteristics of finished construction products, which distinguishes it from the products of other industries, you can define the following:

- construction products have a high share of labor inputs (both construction workers, highly skilled engineers, architects, economists, etc.) and are involved in the construction processes, and material consumption, which significantly influences the formation of the final price of the product, which is significantly dependent on fluctuations in prices for external stakeholders - construction materials manufacturing enterprises, 
- construction products have a long service life,

- construction products are fixed, cannot be moved in time or space,

- construction products must be clearly standardized in accordance with building codes, safe to use, environmentally friendly and reliable.

Among the specific features of the construction process itself are the following factors:

- construction process is a long production cycle and therefore has high financial risks in case of fluctuations in the price of construction materials or labor costs, which is difficult to predict in the long run,

- property being erected is static, so the movement is foreseen around by workers, machines and mechanisms, vehicles, etc.

- production process of construction products involves the interaction of a wide range of stakeholders: contractors, subcontractors, investors, local authorities, technical audit services, housing and communal services, consumers, environmental inspections, etc.,
- construction process involves a number of preparatory work, such as the equipping of a construction site, the development of general plans, etc.

- process of construction of a real estate object must be accompanied by processes of infrastructure development of the object, depending on the scale of construction and predeveloped plans: communication, creation of transport infrastructure, construction of playgrounds and other breakouts of social or municipal purpose, and for construction, for example, residential districts, construction of schools, hospitals and other infrastructural facilities in accordance with the urban planning rules for the project of zoning of a new residential district.

The specificity of the construction industry outlined above determines the specificity of the factors influencing the competitiveness of construction enterprises.

Most scientists divide the factors of influence on the competitiveness of the construction industry on the external and internal [5], [6], [7]. We propose to regulate the structure of competitive factors not only in orientation to the internal or external system for the construction company, but also in terms of functional features of the construction enterprises development. The results of the analysis are summarized in Table I.

TABLE I. STRUCTURE OF COMPETITIVENESS FACTORS OF CONSTRUCTION ENTERPRISES [2-4, 8 -11]

\begin{tabular}{|c|c|c|}
\hline \multirow{2}{*}{ Factor group } & \multicolumn{2}{|c|}{ Elements of competitiveness structure } \\
\hline & External & Internal \\
\hline Legal & $\begin{array}{l}\text { Absence of clear legislative norms for regulation of the construction } \\
\text { industry; } \\
\text { Absence of right mechanisms to protect the rights and interests of } \\
\text { contractors, investors, consumers and other participants in the construction } \\
\text { process }\end{array}$ & $\begin{array}{l}\text { Compliance of construction processes with } \\
\text { internal regulations of the enterprise }\end{array}$ \\
\hline $\begin{array}{l}\text { Technical and } \\
\text { technological }\end{array}$ & $\begin{array}{l}\text { Changes to the norms and standards of the construction process and } \\
\text { requirements for finished construction products }\end{array}$ & $\begin{array}{l}\text { High quality assurance requirements, } \\
\text { Working in the conditions of innovative } \\
\text { technological development, } \\
\text { Forms and methods of organization of } \\
\text { construction process and design, } \\
\text { The quality of the finished product }\end{array}$ \\
\hline Economic & $\begin{array}{l}\text { Limited access to credit, high credit rates, } \\
\text { Fluctuations in market conditions, } \\
\text { Inflationary expectations and fluctuations in the national currency, } \\
\text { The level of entrepreneurial activity, } \\
\text { Investment climate in the region }\end{array}$ & $\begin{array}{l}\text { Market conditions research and mobile response } \\
\text { to market demands, } \\
\text { Search and use of material resources, } \\
\text { Innovative investment and financial potential, } \\
\text { Rationalization of pricing processes }\end{array}$ \\
\hline Social & $\begin{array}{l}\text { Living standards and solvency of the population, } \\
\text { Demographics, } \\
\text { Social development of the region }\end{array}$ & $\begin{array}{l}\text { Human resources management, } \\
\text { Marketing technologies, product promotion, } \\
\text { effective brand communications, } \\
\text { Development of the intellectual potential of } \\
\text { the enterprise }\end{array}$ \\
\hline Political & $\begin{array}{l}\text { Political instability, } \\
\text { Change of the governing and coordinating bodies regulating the work of } \\
\text { construction enterprises (profile ministries and agencies), }\end{array}$ & \\
\hline $\begin{array}{l}\text { Relations with } \\
\text { local authorities }\end{array}$ & $\begin{array}{l}\text { Absence of transparent mechanisms of operative work on delivery and } \\
\text { acceptance act, bureaucracy and corporate component }\end{array}$ & \\
\hline
\end{tabular}

Thus, having identified the main factors for the competitiveness of construction enterprises, the impact of their transformations on the formation of urban systems development models can be analyzed.
The model of the correlation between improving the competitiveness of construction enterprises and ensuring the development of urban systems, developed by the authors is presented in table II. 
TABLE II. CORRELATION MODEL TO INCREASE THE COMPETITIVENESS OF CONSTRUCTION ENTERPRISES AND ENSURE THE DEVELOPMENT OF URBAN PLANNING SYSTEMS

\begin{tabular}{|l|l|}
\hline $\begin{array}{l}\text { Factor of construction } \\
\text { enterprises competitiveness }\end{array}$ & Impact on urban development \\
\hline Legal factors & $\begin{array}{l}\text { Improving the regulatory support of the construction industry will help to ensure the transparency of the spatial } \\
\text { and functional organization of cities and territories }\end{array}$ \\
\hline Technical and technological & $\begin{array}{l}\text { Development of technical and technological aspects of construction production will improve the quality and } \\
\text { reliability of real estate, thereby contributing to the provision of comfortable and safe accommodation, transport } \\
\text { accessibility and quality provision of housing and communal services }\end{array}$ \\
\hline Economic & $\begin{array}{l}\text { Economic factors will contribute to improving the efficiency of managing the processes of urban and territorial } \\
\text { development, providing affordable housing, commercial real estate and developing industrial facilities for } \\
\text { economic growth }\end{array}$ \\
\hline Social & $\begin{array}{l}\text { Development of social factors will contribute to the accessibility of the population to the provision of social and } \\
\text { housing needs, will involve the population in the monitoring and public audit processes of construction }\end{array}$ \\
\hline Political & Ensure the stability of urban development systems \\
\hline Relations with local authorities & $\begin{array}{l}\text { Transparency and efficiency of local government will provide process informatization of life support of cities and } \\
\text { territories, automation monitoring and control of social and economic development, involving local people to } \\
\text { solve the problems of cities and territories }\end{array}$ \\
\hline
\end{tabular}

Therefore, having analyzed the factors of ensuring the competitiveness of construction enterprises and their impact on the life support and functioning of urban development systems, we can propose the following ways of forming models of urban development:

- development of legislative projects for urban development and construction sector development based on the introduction of public control and technical supervision over the implementation of construction processes with the involvement of outside experts from the private sector and public organizations, and giving them the opportunity to exercise their powers in parallel with public authorities or bodies by delegating control functions from public authorities, which is a common European practice,

- carrying out a comparative analysis of European Union building and construction standards and national standards, developing appropriate recommendations to bring urban and building standards into line with global best practices in order to ensure the competitiveness of national construction enterprises in European markets, implementing best urban development practices to improve the quality of service delivery the population of cities and territories and the provision of spatial and functional organization in accordance up-to-date trends and tendencies,

- ensuring the development of the investment climate and developing mechanisms for effective investment in the construction industry, determining the responsibility of each party to the contractual relationship, establishing tight control over the performance of contractors, investors, consumers, etc. of their financial obligations in accordance with established contractual relations,

- creating a single system for assessing the potential of a construction enterprise to fulfill its obligations, which will be based on the calculation of the enterprise capacity to determine the ability to perform a certain amount of construction work within the obligations undertaken,

- determination of the mechanisms of social guarantees realization by construction enterprises at the commissioning of the real estate object in operation with regard to ensuring the proper level of social, domestic infrastructure, opportunities for providing quality public utilities, transport accessibility, other objects of urban construction infrastructure, as an obligatory element of ensuring a quality people's life,

- development of information resources on the activity of construction companies with indication of economic, social, technical and technological features of their work, presentation of finished products for involving the population in public monitoring and control of construction and commissioning of real estate objects, opportunities for on-line access to prospective urban development plans to involve the local population in solving urban and territorial development problems .

Analyzing the interdependence of urban planning decisions and their impact on the competitiveness of construction enterprises, as well as by analyzing feedback, it is reasonable to apply simulation modeling. It would be logical to analyze the relationships between indicators that characterize fixed assets and investment flows in the development of urban planning systems. We offer the following model for assessing the interdependence of these indicators - formula 1 .

$$
\mathrm{FA}_{\mathrm{j}}(\mathrm{y})=\mathrm{FA}_{\mathrm{j}} ;(\mathrm{y}-\Delta \mathrm{y})+\Delta \mathrm{y} *\left(\mathrm{FA} \mathrm{I}_{\mathrm{j}}(\mathrm{y})-\mathrm{AFI}_{\mathrm{j}}(\mathrm{y})\right)
$$

where FA - fixed assets

$$
\begin{aligned}
& \text { y - year } \\
& \text { j - type of construction production } \\
& \text { I - the share of all investments }
\end{aligned}
$$

In this model, it is necessary to take into account the timing of fixed assets disposal. There are two assumptions. First, fixed assets can be taken out of production in the same year $y$ as the fixed assets introduced into production. Second, the disposal of fixed assets is calculated exactly taking into account depreciation. The model considers both assumptions.

\section{CONCLUSIONS}

Therefore, the question of ensuring the development of urban planning systems in the context of improving construction enterprises competitiveness is relevant. The urban and territory development in an information oriented 
society sets new priorities for improving governance. The construction industry, as one of the most difficult in terms of the management functions of the economic sectors, is one of the main industries capable of providing maximum comfort and convenience of life for the population in a particular territory. The study contains identification of specific characteristics of the construction industry, on the basis of which factors that directly affect competitiveness were formed. These factors were grouped into the following blocks: regulatory, technical and technological, economic, social, political and in relation to local authorities. An analysis of each factor group revealed their potential impact on urban development. As a result of the analysis, it was determined that the priority on the way of formation of innovative models of urban planning systems development by ensuring high competitiveness of the construction industry is to increase the information component of construction processes, involve the public in monitoring and control, delegation of part of these powers from public to private sector, improvement of legislative support, norms and standards of construction and urban planning activity, ensuring management process of urban and territory development transparency .

\section{REFERENCES}

[1] V. L. Dykan "Reforming the Ukrainian Economy and Competitiveness of Enterprises" : Monograph - Kharkov: Osnova, 1997. - 350 p [in Ukrainian]..

[2] S. A. Shcherbinina, A. V.Kryvoruchenko, I. R. Kiselov "Competitiveness of Construction Enterprises as a Direction for Increasing the Economic Efficiency of Housing" Bulletin of the National University of Water Management and Environmental Management. Economy. - 2014. - Vyp. 1. - S. 419-425. - [Online]. Available: http://nbuv.gov.ua/UJRN/Vnuvgp_ekon_2014_1_49 [in Ukrainian]
[3] T. Ju. Pastuhova, "Methods of Calculating the Competitiveness of an Enterprise, Application of the Theory of Effective Competition" [Online]. Available: http://www.confcontact.com/2012_03_15/ek1_pastuhova.php. [in Ukrainian].

[4] O.Ie. Rossikhina "Competitive Factor Basis of Construction Enterprise Competition" [Text] International Conference: Strategy for Innovative Development of the Ukrainian Economy: Problems, Prospects, Efficiency. Section 2. Business Economics and Marketing. - NTU «KhPY», 2010. _ - [Online]. Available: http://www.kpi.kharkov.ua/archive/Conferences/Стратегіï\%20іннова ційного\%20розвитку \%20економіки\%20України\%20проблеми, \%20перспективи, \%20ефективність/2010/S2/КОНКУРЕНТОУТВ ОРЮЮЧИ\%20ФАКТОРИ.pdf [in Ukrainian].

[5] V. V. Smachylo, I. S. Holovko-Marchenko "Classification of Factors of Impact on the Competitiveness of Enterprises". Young Scientist. 2015. - № 2(17). - S. 61-65. -- [Online]. Available: http://molodyvcheny.in.ua/files/journal/2015/2/128.pdf [in Ukrainian].

[6] Law of Ukraine "On Fundamentals of Urban Planning". Official site of the Verkhovna Rada of Ukraine - [Online]. Available: https://zakon.rada.gov.ua/laws/show/2780-

12/ed20121118/find?text $=\% \mathrm{CC} \% \mathrm{~B} 3 \% \mathrm{~F} 1 \% \mathrm{~F} 2 \% \mathrm{EE} \% \mathrm{E} 1 \% \mathrm{~F} 3 \% \mathrm{E} 4 \% \mathrm{~B}$ $3 \% \mathrm{E} 2 \% \mathrm{ED} \% \mathrm{E} 0+\% \mathrm{E} 4 \% \mathrm{EE} \% \mathrm{EA} \% \mathrm{~F} 3 \% \mathrm{EC} \% \mathrm{E} 5 \% \mathrm{ED} \% \mathrm{~F} 2 \% \mathrm{E} 0 \% \mathrm{~F} 6 \%$ B3\%FF [in Ukrainian].

[7] S. V. Rasskazov A. N. Rasskazova "The image of the company's value and its application in the corporate governance”, Financial management, (2012), vol. 4, pp. 59-68 [in Ukrainian].

[8] Ya.M. Kashuba, "Selection of Methods and Approaches for Strategic Management of Entrepreneurship Development", Economy and State, (2011), vol. 9, pp. 16-18. [in Ukrainian].

[9] V. V. Iatsura and M. V. Zamroz "Analysis of the Methods of Assessing the Competitiveness of Enterprises". Bulletin of the Volyn Institute of Economics and Management. Collection of scientific works.-2011. - № 2 [in Ukrainian].

[10] O. V. Chyzhova "Assessment of Entrepreneurship Competitiveness". Development Management. - 2013. - № 21. - S. 63-65. [in Ukrainian].

[11] P. R. Putsenteilo "Competitiveness of Enterprises: Definition Analysis" Methodology. Innovative Economics: Scientific and Practical Collection. - 2015. - № 4 (59). - S. 80-86. [in Ukrainian]. 